\title{
Parental occupational exposures and the risk of cerebral palsy in children
}

\author{
Raushan Issayeva $^{1}$, Sholpan Karzhaubaeva ${ }^{1}$, Elmira Alibi ${ }^{1},{ }^{*}$ Denis Vinnikov ${ }^{1}$ \\ Sri Lanka Journal of Child Health, 2020; 49(2): 156-161
}

\begin{abstract}
Introduction: Association of parental occupational exposure to chemicals with cerebral palsy $(\mathrm{CP})$ in children remains poorly characterized.
\end{abstract}

Objectives: To ascertain the role of parents' occupational exposure in $\mathrm{CP}$ in children in major Kazakhstan cities using a case-control design.

Method: We enrolled 150 cases, including children one month to 18 years old, and 150 controls in all regions of Kazakhstan. Cases were children with confirmed diagnoses on treatment or rehabilitation, whereas controls were their counterparts with no CP. Exposure to hazardous chemicals of parents at work and other demographics were collected with structured questionnaires, and logistic regression models, crude and adjusted, were used to calculate the odds of $\mathrm{CP}$ in children, expressed as odds ratios (OR) with their $95 \%$ confidence intervals (CI).

Results: Most cases (52\%) were children below one year of age. Prevalence of parents' alcohol use did not differ between the groups, whereas we found more smokers in parents of controls compared to cases. There were more fathers in cases with exposure to chemicals $(21 \%$ vs. $5 \%$ in controls, $\mathrm{p}<0.001)$. Father's occupational chemical exposure increased the odds of $\mathrm{CP}$ in children (OR 18.7 (95\% CI 3.3; 105.7), adjusted for age, sex, father's highest attained education and mother's education; and OR 36.8 (95\% CI 3.6; 370.5) if further adjusted for father's and mother's smoking).

Conclusions: Father's occupational chemical exposure increased the odds of $\mathrm{CP}$ in children (OR 18.7 (95\% CI 3.3; 105.7), adjusted for age, sex, father's highest attained education and mother's education

\footnotetext{
${ }^{1}$ Al-Farabi Kazakh National University, Almaty, Kazakhstan

*Correspondence: denisvinnikov@mail.ru iD. orcid.org/0000-0003-0991-6237
}

(Received on 21 August 2019: Accepted after revision on 18 October 2019)

The authors declare that there are no conflicts of interest

Open Access Article published under the Creative

Commons Attribution CC-BY (CC) (†) License
DOI: http://dx.doi.org/10.4038/sljch.v49i2.8965

(Key words: cerebral palsy, occupational, regression, case-control)

\section{Introduction}

The prevalence of cerebral palsy (CP) may range depending on age, and the polled estimate from meta-analysis was 2.1 per 1000 live births ${ }^{1}$. A wide range of risk factors for $\mathrm{CP}$ have been studied and reported. In China, a study showed that the prevalence of CP in multiple births was 9.7 per 1000 children, 6.5 times that in singletons ${ }^{2}$. Genetic factors, such as genetic polymorphism of NOS1 gene $^{3}$ and environmental factors, such as exposure to methyl mercury during pregnancy, iodine deficiency ${ }^{4}$ and even high blood lead levels ${ }^{5}$ may be important, but perinatal causes remain the leading cause of $\mathrm{CP}^{6}$, especially small for gestational age ${ }^{7}$. Caesarean delivery was believed to be associated with $\mathrm{CP}$, but a systematic review found no association ${ }^{8}$.

Environmental factors and their potential for $\mathrm{CP}$ attract attention, since a huge fraction of population still resides in polluted cities, and the level of chemical exposure is growing, especially in developing nations. A recent study in China showed that father's occupational exposure increased the risk 3-fold ${ }^{9}$. In Kazakhstan, noted for high level of environmental pollution in major cities and occupational exposure from the remaining industry, these environmental contributors may play a role, but no analysis was published from Kazakhstan in the recent years.

\section{Objectives}

To ascertain the role of parents' occupational exposure in the greater likelihood of $\mathrm{CP}$ in children in the major Kazakhstan cities using a case-control design.

\section{Method}

This was a case-control study of the association of occupational exposure of either of the parents with $\mathrm{CP}$ in children. Cases were children of one month to 18 years old, identified by the medical personnel of the charity organization, which is actively involved in rehabilitation of children with $\mathrm{CP}$ in all regions of Kazakhstan. These cases were all with confirmed diagnoses, all on the state register and receiving rehabilitation. Neurological deficit was different in cases, as was the functional status of selected motor activities. The study protocol was 
approved by the Local Committee on Bioethics of the Kazakh Medical University of Continuing Education (Minutes \#1 dated September 20, 2017).

In total, we enrolled 150 cases with 150 controls using 1:1 ratio. For sample size calculation, we use data from the previous study where they reported occupational exposure of fathers ${ }^{9}$. Although we tried to enroll subjects from all regions of Kazakhstan, the sample was mostly constructed from residents of the largest city, Almaty along with the province surrounding it (Table 1).

Table 1: The distribution of cases and controls from the regions within the country

\begin{tabular}{|l|c|c|c|}
\hline & $\begin{array}{c}\text { Cases } \\
\text { Number (\%) }\end{array}$ & $\begin{array}{c}\text { Controls } \\
\text { Number (\%) }\end{array}$ & $\begin{array}{c}\text { Total } \\
\text { Number (\%) }\end{array}$ \\
\hline No answer & $13(09)$ & $0(0)$ & $13(04)$ \\
\hline Almaty & $33(22)$ & $90(60)$ & $123(41)$ \\
\hline Astana & $17(11)$ & $01(01)$ & $18(06)$ \\
\hline Aktubinsk province & $38(25)$ & $0(0)$ & $23(08)$ \\
\hline Akmola province & $23(15)$ & $0(0)$ & $73(24)$ \\
\hline Almaty province & $19(13)$ & $54(36)$ & $04(01)$ \\
\hline Atyrau province & $04(03)$ & $0(0)$ & $01(0)$ \\
\hline East Kazakhstan province & $01(01)$ & $0(0)$ & $0(0)$ \\
\hline Jambyl province & $0(0)$ & $0(0)$ & $02(01)$ \\
\hline Karaganda province & $0(0)$ & $02(01)$ & $01(0)$ \\
\hline Kostanay province & $0(0)$ & $0(0)$ & $0(0)$ \\
\hline Kyzylorda province & $0(0)$ & $01(01)$ & $01(0)$ \\
\hline Mangystau province & $0(0)$ & $0(0)$ & $01(0)$ \\
\hline Pavlodar province & $01(01)$ & $0(0)$ & $01(0)$ \\
\hline North Kazakhstan province & $0(0)$ & $01(01)$ & $0(0)$ \\
\hline South Kazakhstan province & $01(01)$ & & \\
\hline
\end{tabular}

Exposure was ascertained using a structured questionnaire, which was offered to each child's mother and consisted of 150 questions covering demographics of a child and parents as well as parents' lifestyle and occupational and environmental exposures. Demographic part included questions on sex, age, place of birth and place of current residence, ethnic origin, family composition at a time of birth and at a time of survey, and highest attained education of father and mother. We then asked whether any parent was a smoker some time before delivery or used any alcohol for some time before delivery. Finally, this part of the questionnaire contained questions on the age of mother and father at a time of child's birth. Occupational history contained two questions separately for each parent, including the one whether he/she was exposed to chemical, biological or physical occupational factors for at least one year and whether his/her workplace were enlisted as unfavourable for the state regulatory bodies. Should they answer 'yes' to the first occupational question, they were asked to categorize exposure to chemical, biological of physical.

We analysed both continuous and binary data in this report. Data were tested for normality and should this be confirmed, cases were compared to controls using t-test, or Mann-Whitney U-test as an alternative. Binary data were tested using $\chi^{2}$ test. In the univariate analysis, we calculated odds ratios (OR) with their corresponding 95\% confidence intervals (CI). In case of $p<0.05$ in the univariate comparisons, we also applied multiple logistic regression to adjust for potential confounding, however, only those variables were treated as confounders if it was considered plausible to place a potential confounder of a causal pathway from the exposure to the outcome in the directed acyclic graph (DAG) analysis. We performed all calculations using NCSS12 (Utah, USA), and pvalues below 0.05 were considered significant (type 1 error below 5\%).

\section{Results}

Most cases were children below one year of age, whereas controls were mostly teenagers (Table 2). We also found significant differences in most included variables related to family composition and educational levels of parents. Thus, there were significantly more boys, not full families (one parent only) and families with more children in $\mathrm{CP}$ group compared to controls. With regard to parents' educational levels, CP children were more likely to be born in families with smaller likelihood of either parents to have a university degree. 
Table 2: Univariate analysis of baseline demographic variables and other confounders

\begin{tabular}{|c|c|c|c|}
\hline Variable & $\begin{array}{c}\text { Cases } \\
\text { Number }(\%)\end{array}$ & $\begin{array}{c}\text { Controls } \\
\text { Number }(\%)\end{array}$ & p-value \\
\hline $\begin{array}{l}\text { Age } \\
29 \text { days- }<1 \text { year } \\
1-3 \text { years } \\
4-6 \text { years } \\
\text { 7-11 years } \\
12-18 \text { years }\end{array}$ & $\begin{array}{l}78(52) \\
45(30) \\
04(03) \\
11(07) \\
12(08)\end{array}$ & $\begin{array}{l}03(02) \\
18(12) \\
24(16) \\
52(16) \\
53(35)\end{array}$ & 0.001 \\
\hline $\begin{array}{l}\text { Sex } \\
\text { Male } \\
\text { Female }\end{array}$ & $\begin{array}{l}85(57) \\
65(43)\end{array}$ & $\begin{array}{l}61(41) \\
89(59)\end{array}$ & 0.01 \\
\hline $\begin{array}{l}\text { Ethnicity } \\
\text { Kazakh } \\
\text { Russian } \\
\text { Other }\end{array}$ & $\begin{array}{l}89(53) \\
35(23) \\
26(17)\end{array}$ & $\begin{array}{l}73(49) \\
40(37) \\
37(25)\end{array}$ & 0.14 \\
\hline $\begin{array}{l}\text { Family composition } \\
1 \text { kid } \\
2 \text { kids } \\
3 \text { kids } \\
4 \text { kids } \\
5 \text { kids or more }\end{array}$ & $\begin{array}{l}53(35) \\
42(28) \\
33(22) \\
14(09) \\
08(05)\end{array}$ & $\begin{array}{l}81(54) \\
66(44) \\
03(02) \\
0(0) \\
0(0)\end{array}$ & 0.001 \\
\hline $\begin{array}{l}\text { Family } \\
\text { Full } \\
\text { Not full }\end{array}$ & $\begin{array}{l}98(65) \\
52(35) \\
\end{array}$ & $\begin{array}{c}146(97) \\
04(03) \\
\end{array}$ & 0.001 \\
\hline $\begin{array}{l}\text { Mother's highest attained education } \\
\text { None } \\
\text { High school } \\
\text { College } \\
\text { University }\end{array}$ & $\begin{array}{c}0(0) \\
25(17) \\
116(77) \\
10(07)\end{array}$ & $\begin{array}{l}45(30) \\
04(03) \\
78(52) \\
23(15)\end{array}$ & 0.001 \\
\hline $\begin{array}{l}\text { Father's highest attained education } \\
\text { None } \\
\text { High school } \\
\text { College } \\
\text { University }\end{array}$ & $\begin{array}{c}01(01) \\
39(26) \\
100(67) \\
10(07)\end{array}$ & $\begin{array}{c}46(31) \\
0(0) \\
77(51) \\
27(18)\end{array}$ & 0.001 \\
\hline
\end{tabular}

Note: $p$-values are from $\chi^{2}$ tests from $2 * X$ tables, where $X$-count rows.

With regard to self-reported addictions and lifestyle attributes, such as smoking and alcohol, bivariate analysis failed to confirm the association of alcohol use in parents with the likelihood of $\mathrm{CP}$ in children (Table 3). In both groups, alcohol use prevalence in fathers was quite high, reaching $70 \%$ in families where CP were born. On the contrary, smoking was far less prevalent in both groups. In addition, both parents were much more likely to smoke in families with healthy children, reflecting greater number of parents with no education at all in the control groups. Occupational chemical exposure of father, as opposed to the one of mother, was associated with greater odds of having a CP child (OR 19.3 $(95 \%$ CI $4.5 ; 82.2))$. The use of an alternative classification of occupational exposure, such as working on a position at any time, classified as hazardous, yielded positive association for both father and mother (Table 3). The table shows that $61 \%$ of mothers having CP child were employed in such workplaces, as opposed to only $1 \%$ of mother heaving healthy children. Somewhat similar association was found when father jobs were considered. 
Table 3: Smoking, alcohol and occupational exposures of parents in cases compared to controls

\begin{tabular}{|c|c|c|c|}
\hline Variable & $\begin{array}{c}\text { Cases } \\
\text { Number }(\%)\end{array}$ & $\begin{array}{c}\text { Controls } \\
\text { Number }(\%)\end{array}$ & p-value \\
\hline $\begin{array}{l}\text { Mother's smoking } \\
\text { Yes } \\
\text { No }\end{array}$ & $\begin{array}{c}01(01) \\
149(99)\end{array}$ & $\begin{array}{l}56(37) \\
94(63)\end{array}$ & 0.001 \\
\hline $\begin{array}{l}\text { Father's smoking } \\
\text { Yes } \\
\text { No }\end{array}$ & $\begin{array}{c}43(29) \\
107(71)\end{array}$ & $\begin{array}{l}90(60) \\
60(40)\end{array}$ & 0.001 \\
\hline $\begin{array}{l}\text { Mother's alcohol } \\
\text { Yes } \\
\text { No }\end{array}$ & $\begin{array}{c}15(10) \\
135(90)\end{array}$ & $\begin{array}{c}23(15) \\
127(85)\end{array}$ & 0.16 \\
\hline $\begin{array}{l}\text { Father's alcohol } \\
\text { Yes } \\
\text { No }\end{array}$ & $\begin{array}{c}105(70) \\
45(30)\end{array}$ & $\begin{array}{l}95(63) \\
55(37)\end{array}$ & 0.22 \\
\hline $\begin{array}{l}\text { Mother's occupational chemical exposure } \\
\text { Yes } \\
\text { No }\end{array}$ & $\begin{array}{l}51(34) \\
99(66)\end{array}$ & $\begin{array}{l}52(35) \\
98(65)\end{array}$ & 0.90 \\
\hline $\begin{array}{l}\text { Father's occupational chemical exposure } \\
\text { Yes } \\
\text { No }\end{array}$ & $\begin{array}{c}32(21) \\
118(79)\end{array}$ & $\begin{array}{c}07(05) \\
143(95)\end{array}$ & 0.001 \\
\hline $\begin{array}{l}\text { Mother's classified hazardous job } \\
\text { No } \\
\text { Yes }\end{array}$ & $\begin{array}{l}58(39) \\
92(61) \\
\end{array}$ & $\begin{array}{c}149(99) \\
01(01) \\
\end{array}$ & 0.001 \\
\hline $\begin{array}{l}\text { Father's classified hazardous job } \\
\text { No } \\
\text { Yes }\end{array}$ & $\begin{array}{c}30(20) \\
120(80)\end{array}$ & $\begin{array}{c}150(100) \\
0(0)\end{array}$ & 0.001 \\
\hline
\end{tabular}

Age, sex and the highest attained education of both parents differed between the groups in the bivariate analyses, therefore, they were included in the models as confounders on the pathway between the occupational exposure of parents and the odds of having a CP child. Model 1 in Table 4 shows that father's occupational chemical exposure in adjusted models increased the likelihood 18.7-fold. Mother's hazardous job was a very strong predictor of having a child with $\mathrm{CP}$ with a very strong association in an adjusted model. Because smoking of either parent can have an association with the likelihood of high occupational exposure, we considered smoking as an important confounder on a pathway between parents' occupational exposure and CP in their children. Therefore, we additionally adjusted the models with smoking status of both parents. Table 4 demonstrates that adjustment for smoking status resulted in even a stronger effect of father's occupational exposure on a chance of having a child with CP. Adjustment for smoking in mother reduced the effect, reflecting on the correlation between mother's smoking and the chance of having a hazardous job. Overall, both father's occupational chemical exposure (OR 36.8 (95\% CI 3.6; 370.5)) and mother's hazardous job (OR 86.1 (95\% CI 9.0; 828.0)) were very strong predictors of $\mathrm{CP}$ in their children.

Table 4: Regression analysis of selected predictors for CP in cases and controls

\begin{tabular}{|l|c|c|c|}
\hline & Crude OR & Model 1 & Model 2 \\
\hline Father's occupational chemical exposure & $19.3(4.5 ; 82.2)$ & $18.7(3.3 ; 105.7)$ & $36.8(3.6 ; 370.5)$ \\
\hline Mother's classified hazardous job & $236.3(32.2 ; 1375.6)$ & $118.7(15.1 ; 930.9)$ & $86.1(9.0 ; 828.0)$ \\
\hline Father's classified hazardous job & Unstable model & Unstable model & Unstable model \\
\hline
\end{tabular}

Note: OR - odds ratio; Model 1 adjusted for age, sex, father's highest attained education and mother's education; Model 2 adjusted for age, sex, father's highest attained education, mother's education, father's smoking and mother's smoking.

\section{Discussion}

This is the first presentation from Kazakhstan on the occupational exposure of parents as a risk factor for $\mathrm{CP}$ in their children. In this case-control study we found a very high risk of $\mathrm{CP}$ in children when either father was exposed to chemicals at work or mother was employed in a hazardous workplace.
Compared to few other studies on such association, the effect in the current study appears to be very strong even in adjusted models. Taken together, this necessitates improved counseling in those planning to have children in the near future as well as planning and implementation of wider studies with better exposure assessment in order to determine which specific occupational exposures may be attributable to the risk. 
Existing evidence on the potential association of CP with parents' occupational exposure is very scarce. Chinese paper is one of very few ${ }^{9}$, if any, to highlight 3-fold increase in the risk, whereas other presentations on CP risk factors do not focus on the occupational causes at all. Because epidemiological evidence is insufficient, speculations over the biological plausibility did not attract much attention so far. The nature of such occupational exposure likely plays a role, because the range of potential hazardous substances and their effects may be too wide. The current analysis showing that $21 \%$ of fathers of CP children vs. 5\% of fathers in controls taken together with very high prevalence of hazardous jobs in mothers in $\mathrm{CP}$ group resulted in very high ORs of the disease with wide 95\% confidence intervals. Apparently, these exposures are important to induce or promote pathology entailing $\mathrm{CP}$ in children, but the effect measures have to be confirmed in other populations.

Our study has a number of strengths including sufficient statistical power resulting from the sample size, inclusion of children from all provinces of Kazakhstan, and the use of detailed questionnaire for parents ascertaining parental risk factors. However, a number of limitations should also be noted. First and most important was some potential for exposure misclassification. We did not obtain detailed work history of each parent from their employers or other reliable sources and used self-reported information instead. No job-exposure matrix was used in this analysis for exposure classification. Moreover, we had to limit occupational history collection to 4 questions only covering a very broad range of potential chemical exposures. With the evidence evolving from our study on a strong association of parental occupational exposure with CP in children, future studies should collect detailed exposure history for selected chemicals and work duration. Secondly, higher prevalence of occupational exposures in the main group may result from differential exposure classification bias, or recall bias, frequently reported from case-control studies of serious medical conditions and disease in children. This recall bias, if any, may produce high prevalence of exposure in cases and low prevalence of parental exposure in controls, yielding elevated ORs.

Our findings have a number of implications for prevention. Kazakhstan, in Soviet times, was a very developed industrial region, where groups of plants and factories in chemical, metallurgical or mining industries formed clusters, situated close to or within the large cities, such as Shymkent or UstKamenogorsk. At present, most of that powerful industry has collapsed, leaving a few locations with populations exposed to hazardous substances in the workplace. Local population and workers are exposed to heavy metals, solvents, reactive chemicals, such as in the metallurgic industry in the East health effects of chemical exposure to metals is well documented, exposure levels may be quite high, as shown in studies from similar industries ${ }^{10}$, however prevention programmes have not been targeted to reduce the burden for reproductive health, and a greater likelihood of $\mathrm{CP}$ in those exposed, as on the current study, has not received sufficient attention. Compliance with regulations remains understudied, and the true exposure levels of the working population remain very poorly documented.

Kazakhstan claimed transfer to cleaner and energyefficient technologies in recent years, hosting Expo-2017, promoting wider implementation of green energy, but the size of population, still exposed to workplace hazards from older industries may still be very high. For environmental health science research, the nature of chemical exposure of those employed in hazardous workplaces in the country remains very poor characterized, since the access to employer's documentation is very limited. Workers are likely unaware of chemical exposure, therefore, family planning does not imply discussion on the potential risks from work. This study raises concern over the need to set up a system of educations for employees in the hazardous workplaces, as well as the need for counseling and informing primary care doctors managing young women in the reproductive age planning to have children in future.

This first presentation on the association of occupational chemical exposures of parents with $\mathrm{CP}$ in their children confirmed a few earlier presentations that father's exposure could increase the odds of the disease. The study uncovered the need for proactive counseling of parents about the risk, whereas the mitigation of chemical exposure of parents is proposed for the time of pregnancy planning.

\section{Conclusions}

Father's occupational chemical exposure increased the odds of CP in children (OR 18.7 (95\% CI 3.3; 105.7), adjusted for age, sex, father's highest attained education and mother's education

\section{References}

1. Oskoui M, Coutinho F, Dykeman J, Jetté N, Pringsheim T. An update on the prevalence of cerebral palsy: a systematic review and meta-analysis. Developmental Medicine and Child Neurology 2013; 55(6):509-19.

https://doi.org/10.1111/dmcn.12080

PMid:23346889 
2. Liu J, Li Z, Lin Q, Zhao P, Zhao F, Hong $\mathrm{S}$, et al. Cerebral palsy and multiple births in China. International Journal of Epidemiology 2000; 29(2):292-9. https://doi.org/10.1093/ije/29.2.292 PMid:10817128

3. Yu T, Xia L, Bi D, Wang Y, Shang Q, Zhu D, et al. Association of NOS1 gene polymorphisms with cerebral palsy in a Han Chinese population: a case-control study. BMC Medical Genomics 2018; 11(1):56. https://doi.org/10.1186/s12920-018-03746

PMid:29940959 PMCid:PMC6019815

4. Pharoah POD, Buttfield IH, Hetzel BS. Neurological damage to the fetus resulting from severe iodine deficiency during pregnancy. International Journal of Epidemiology 2012; 41(3):589-92.

https://doi.org/10.1093/ije/dys070

PMid:22586135

5. Bansal N, Aggarwal A, Faridi MMA, Sharma T, Baneerjee BD. Association of lead levels and cerebral palsy. Global Pediatric Health 2017; 4: 2333794X17696681. https://doi.org/10.1177/2333794X1769668 1

PMid: 28491920 PMCid: PMC5406142

6. Monokwane B, Johnson A, GambrahSampaney C, Khurana E, Baier J, Baranov $\mathrm{E}$, et al. Risk factors for cerebral palsy in children in Botswana. Pediatric Neurology 2017; 77:73-7. https://doi.org/10.1016/j.pediatrneurol.201 7.07.014

PMid: 29074060

7. Zhao M, Dai H, Deng Y, Zhao L. SGA as a risk factor for cerebral palsy in moderate to late preterm infants: a system review and meta-analysis. Scientific Reports 2016; 6:38853.

https://doi.org/10.1038/srep38853

PMid: 27958310 PMCid: PMC5153647

8. O’Callaghan M, MacLennan A. Caesarean delivery and cerebral palsy: A systematic review and meta-analysis. Obstetrics \& Gynecology 2013; 122(6):1169.

https://doi.org/10.1097/AOG.0000000000 000020

PMid:24201683

9. Gao J, Zhao B, He L, Sun M, Yu X, Wang L. Risk of cerebral palsy in Chinese children: A N: M matched case control study. Journal of Paediatrics and Child Health 2017; 53(5):464-9.

https://doi.org/10.1111/jpc.13479

PMid: 28134474

10. Vinnikov D, Semizhon S, Rybina $T$, Zaitsev V, Pleshkova A, Rybina A. Occupational exposure to metals and other elements in the tractor production. Plos One 2018; 13(12): $\mathrm{e} 0208932$. https://doi.org/10.1371/journal.pone.0208 932

PMid: 30550545 PMCid: PMC6294428 